\section{BIRDS OF THE ELBOW}

J. Frank Roy. 1996. Special Publication No. 21. Saskatchewan Natural History Society, Regina. 325 pp. $\$ 30.00$ (Available from the Blue Jay Bookshop)

This is the third in a series of publications supported in large part by funds provided by the late Manley Callin. As the author states: "The ultimate purpose of this book and others in the Callin series is to help Saskatchewan people appreciate the natural heritage which is theirs - a heritage to enjoy now and to preserve for generations to follow." Manley Callin would, I think, be pleased with this informative and well-illustrated work which so aptly meets that objective.

Measuring about $8 \times 11$ inches, with 30 colour photographs and 26 drawings, this is a sumptuous production. In a delightful foreword Margaret Belcher notes: "The extensive area he covers in the southwest of the province is country into which Frank Roy longs to take the reader, for whom he plots myriad expeditions to his 'birding spots'." The photos, by George Tosh and the author, shatter the myth of the "endless flat prairie." l've seen some of the area, having been fortunate enough to attend a SNHS field meet at Beechy, but even so I was overwhelmed by the beauty and grandeur of the views of that abrupt bend in the South Saskatchewan River known as the Elbow. This is a serious and exhaustive compilation of all known bird records for an area which is, according to the author, "three times the size of Prince Edward Island," with an appropriate analysis of the significance of the information.

Birds of the Elbow covers 301 species, of which 131 are known to have nested, plus another 11 which are believed to breed. The challenge for young naturalists living in or near the Elbow is to help fill in the gaps which Roy identifies - find that first Bobolink nest! As one might expect from a teacher of English, the species accounts are informative and lively, with a good combination of factual and anecdotal material. Easy to read, the accounts tell how and where to find and identify the subjects, give spring and fall migration dates and numbers, nesting data, life history notes, winter records, and banding information, the latter surprising us with numbers and results of banding recoveries. It is clear that the author has had much experience in both the field and the library. His presence though constant, is not intrusive. We can share his enjoyment of birds in such direct statements as this opening line for the Fox Sparrow account: "I look forward to transient Fox Sparrows." Though a serious birder and scholar, Roy's wry sense of humour emerges now and then; in describing the amenities at one good birding spot he notes: "The pit toilets in this area are open all year, although in winter you may have to shovel snow to get the door open!"

For a reference book of this size and weight, the cover material seems a little thin. My copy has already frayed on the back corners. I could wish, too, that the excellent photographs had been left with a little margin rather than being tightly bound into the centre, as is true for several. The drawings vary greatly in quality, the 26 by Trevor Herriot ranging, in my opinion, from fine (Eared Grebe, Wilson's Phalarope) to poor (American Goldfinch, 
Ferruginous Hawk). Herriot's Ferruginous Hawk hovering over a nest is just anatomically impossible. Most of the drawings could have been much reduced. This would have provided space to remedy the annoying separation of species account lead from the body of the text - this happens 14 times. Although only a minor distraction when the text follows on the page opposite, in 10 instances the species name sits alone at the bottom of a page, with the text appearing overleaf. This curious fault should have been caught by the layout people. Despite the usual intensive search for typos, I found only three, none of significance (one, $p$. 271, two, p. 306); someone worked hard! The author was able to incorporate the latest name changes, not an easy task in these days of nomenclatural shifting. I noted one small slip in this connection - in the discussion of hybrid flickers (p. 44) the names used don't jibe with the names given in the species accounts. And I take it that the omission of the title "Pigeons" for the aptly descriptive poem on p. 181 is another small slip.

This book provides information on geology, topography, ecology, history, conservation, land use, etc. - it is much more than a bird book. The 19 maps will aid anyone seeking access to the Elbow country; Roy's numerous polite reminders to respect landowner's right should benefit all concerned. With its many fine features, Birds of the Elbow sets a fine example, whether as a regional report, a provincial or state bird book. It fills a large gap in the ornithology of the Northern Great Plains. It's a lot of book for the money. Well done, Frank!

- Reviewed by Robert W. Nero, 546 Coventry Road, Winnipeg, MB. R3R 1B6

\section{MY LITTLE BOOK OF BURROWING OWLS}

HOPE IRVIN MARSTON, illustrated by Maria Magdalena Brown. 1995. Published by NorthWood Press, Inc. $\$ 8.00$ (Available at Blue Jay Bookshop)

Ms. Marston's book brings the reader through the arrival of a Burrowing Owl pair settling on the prairies for the summer. The story follows the owls as they prepare their summer nest, and raise a family on the prairie grassland. The reader is taken into the lives of the owls, and is given a description of some of the dangers the young owls face as they grow up.

Bright, eye-catching illustrations by Maria Magdalena Brown accompany Ms. Marston's simple story. Despite minor inaccuracies (i.e. the Burrowing Owls are depicted with feathered legs when, in actuality, their legs are bare), the book captures the engaging mannerisms of the endangered owls. The prairie grasses and flowers in the landscape are drawn with beautiful detail. The simple story, and colourful illustrations should appeal to any child more eager to look than listen!

\section{- Reviewed by Neeru Verma}

\section{THE WHOOPING CRANE}

JEROME J. PRATT. 1996. Rose Printing Co., Inc. Tallahassee, Florida, U.S.A. 171 pp. \$17.95. (Available from Castle Rock Publishing, 1712 Pine Woods Road, Prescott, Arizona, USA 86301)

The back cover of this soft-cover book proclaims that aviculturists, biologists, zookeepers and government officials were responsible for the success in the recovery efforts for the Whooping Crane. The 